\title{
REPRESENTATIONS OF VULNERABILITY AND EMPOWERMENT OF NURSES IN THE CONTEXT OF HIV/AIDS ${ }^{1}$
}

\author{
Érick Igor dos Santos², Antonio Marcos Tosoli Gomes ${ }^{3}$, Denize Cristina de Oliveira ${ }^{4}$
}

\footnotetext{
${ }^{1}$ Excerpt from the dissertation - Vulnerabilidade de enfermeiros no cuidado a pacientes com HIV/aids: Um estudo de representações sociais, submitted to the Graduate Program in Nursing, School of Nursing, State University of Rio de Janeiro, 2012.

2 Ph.D. in Nursing. Assistant Professor of the Department of Nursing, Fluminense Federal University. Rio de Janeiro, Brazil. Email: eigoruff@gmail.com

${ }^{3}$ Ph.D. in Nursing. Professor of the School of Nursing, State University of Rio de Janeiro. Rio de Janeiro, Brazil. Email: mtosoli@ gmail.com

${ }^{4}$ Ph.D. in Nursing. Professor of the State University of Rio de Janeiro. Rio de Janeiro, Brazil. Email: dcouerj@gmail.com
}

\begin{abstract}
The aim of this study was to analyze the social representations of vulnerability and empowerment of nurses, in the context of their relationships with the work environment, in which they care for people with HIV/AIDS. A qualitative and descriptive study was carried out with 30 nurses in a public hospital that is a reference for HIV/AIDS care. The theoretical framework of the procedural approach from the Social Representations Theory was adopted. The interviews were transcribed and submitted to thematic content analysis using the software Nvivo 9.0. Vulnerability was expressed as embarrassment, dissatisfaction, distress, frustration, insecurity, overload and stress. In turn, empowerment was expressed in the form of positive interpersonal relationships, moral and operational support from the team, adaptations and improvisations, acquisition of scientific knowledge, and professional self-protection.
\end{abstract}

KEYWORDS: Health vulnerability. Nursing care. Acquired immunodeficiency syndrome. Nurses. Occupational health.

\section{REPRESENTAÇÕES DA VULNERABILIDADE E DO EMPODERAMENTO POR ENFERMEIROS NO CONTEXTO DA AIDS}

RESUMO: Esta pesquisa objetivou analisar as representações sociais da vulnerabilidade e do empoderamento elaboradas por enfermeiros, no contexto das relações mantidas no ambiente de trabalho, no qual cuidam de pessoas com HIV/aids. Trata-se de pesquisa qualitativa e descritiva, realizada com trinta enfermeiros de um hospital público de referência em HIV/aids. Adotou-se o referencial da abordagem processual da Teoria das Representações Sociais. As entrevistas foram transcritas e submetidas à análise de conteúdo temática instrumentalizada pelo software Nvivo 9.0. A vulnerabilidade foi expressa em constrangimento, insatisfação, angústia, frustração, insegurança, sobrecarga e estresse. Já o empoderamento foi expresso sob a forma de relacionamento interpessoal favorável, apoio moral e operacional por parte da equipe, adaptações e improvisações, obtenção de conhecimento científico e autoproteção profissional. Conclui-se que os enfermeiros carecem de políticas promotoras de um ambiente de trabalho mais saudável.

PALAVRAS CHAVE: Vulnerabilidade em saúde. Cuidados de enfermagem. Síndrome da imunodeficiência adquirida. Enfermeiros. Saúde do trabalhador.

\section{REPRESENTACIONES DE LA VULNERABILIDAD Y EMPODERAMIENTO POR ENFERMEROS EN EL CONTEXTO DEL SIDA}

RESUMEN: El objetivo fue analizar las representaciones sociales de la vulnerabilidad y empoderamiento elaboradas por enfermeros en el contexto de las relaciones que mantienen con el ambiente de trabajo en el que cuidan de personas con VIH/Sida. Esta es una investigación cualitativa y descriptiva, realizada con 30 enfermeros de un hospital público de referencia en el VIH/Sida. Se adoptó el referencial del abordaje procesal de la Teoría de las Representaciones Sociales. Las entrevistas fueron transcritas y sometidas al análisis de contenido temático por medio del programa Nvivo 9.0. La vulnerabilidad fue expresa en forma de encogimiento, insatisfacción, angustia, frustración, inseguridad, sobrecarga y estrés. Ya el empoderamiento, fue expreso en forma de relación interpersonal favorable, apoyo moral y operativo por parte del equipo, adaptaciones e improvisaciones, obtención de conocimiento científico y autoprotección profesional.

PALABRAS CLAVE: Vulnerabilidad en salud. Atención de enfermería. Síndrome de inmunodeficiencia adquirida. Enfermeros. Salud laboral. 


\section{INTRODUCTION}

Despite the theoretical construct of vulnerability being broadly used in various areas of knowledge, including health and nursing, some studies have defended its non-crystallization, and the need to revisit and constantly question its fundamental aspects. Based on this statement, studies that portray how different social groups conceive of their vulnerability are important, as well as studies that show the knowledge and practices nurses use to reduce vulnerability through empowerment. Moreover, examination of the incorporation of this concept by health professionals is necessary, as well as how they organize individually and/or collectively to tackle the fragility present in various contexts of health care, either in primary, secondary or tertiary care. ${ }^{1-2}$

The object of this study consist of the social representations of vulnerability and empowerment developed by nurses in the context of their relationships with their working environment, in which they care for people living with HIV/ AIDS in the hospital setting. Its aim, therefore, was to analyze the social representations of vulnerability and empowerment developed by nurses, in the context of the relationships they keep with their working environment under the auspices of HIV/ AIDS. Vulnerability is understood as a dynamic and changeable state of frailty, or a typically human disability, with different dimensions, being the result of several factors and situations that are intrinsic and extrinsic to health care system patients, or the professionals charged with their care. The state of vulnerability impels the formulation of coping strategies that facilitate empowerment in face of the experience of the health-illness care procedure. The threats experienced risk the continuity of their existence, the quality of life that they have or can attain, as well as the social fabric in which they are included, both in the everyday of being cared for or a caregiver, taking into account their individual characteristics, the stage of the disease, the setting that the care assumes when psychosocially reconstructed, and the sociocultural context that surrounds it. ${ }^{1-2}$

In the context of nursing care, vulnerability is not restricted to susceptibility of contamination by some pathogen. Despite comprehending the universe of social, individual, political and institutional factors, which put individuals at risk of acquiring diseases in the hospital environment, it encompasses everything that represents a threat to the physical, moral, mental, spiritual, social or affective integrity of nursing professionals. ${ }^{1-5}$

This study is supported by previous studies, whose results point to important characteristics of vulnerability in the set of knowledge and practices cited by nurses and other nursing professionals. These studies have highlighted the fear of exposure to communicable diseases in the hospital, the psychophysical wear caused by being overwhelmed by providing care, and lack of supplies, equipment and sufficient staff, conflicts between personal and institutional values, and lack of motivation for work. ${ }^{6-8}$

\section{METHODS}

The Social Representations Theory was adopted as the theoretical-methodological approach of this study, with its processual approach developed from the perspective of social psychology. The processual approach was chosen to guide the research because it targets the constitutive aspects of the representations, a characteristic that aids understanding of the object of study, outlined in its multiple intervening factors, and because of the complexity presented by the object of representation. ${ }^{9-10}$

The study population was composed of 30 nurses who work in the scenario chosen for the research, a municipal hospital in Rio de Janeiro that is a reference for the treatment of people living with HIV/AIDS and/or tuberculosis. This number was established because it is recognized in the Social Representations Theory as being the minimum quantity to recover the social representations of a group. ${ }^{10-11}$ Professionals with less than six months of professional activity in the context chosen were excluded. This is due to the factor of time being a determinant in the development of social representations. No other attribute was constituted as a criterion for justifiable exclusion.

The data collection techniques chosen were a sociodemographic questionnaire to characterize the subjects and a semi-structured interview. Data were collected between June and August of 2009. The interviews were transcribed and analyzed using the theoretical and methodological postulates of Social Representations. The analysis technique chosen was Thematic Content Analysis, ${ }^{12}$ after systematization $^{13}$ and operationalization by the QSR NVivo 9.0 software. This computerized tool is based on the principle of coding and storage of text clippings into themes (nodes), grouped into 
categories (tree nodes) in a computerized manner. ${ }^{2}$ The construction of categories was performed so as to reorganize the social thought of the group investigated, in order to capture the constituent processes of representational dimensions of vulnerability and empowerment, especially those related to processes of objectification and anchoring. The study was developed with the aim to comply with the ethical principles of research involving human beings set out in the Declaration of Helsinki and Resolutions n. 196/96 and n. 466/12 of the National Health Council (NHC), of the Ministry of Health $(\mathrm{MOH})$ of Brazil. The project to which this study pertains was submitted to the Ethics Committee of the Municipality of Rio de Janeiro, and obtained approval under protocol n. 200/08.

\section{RESULTS}

The majority of study participants were women (87\%), aged between $41-45$ years (27\%), Roman Catholics (40\%), living with a partner $(70 \%)$, with latu-sensu graduate degree $(90 \%)$, with 16 or more years of institutional work (37\%), 16 or more years of work with people living with HIV/ AIDS (30\%), performing care work at the time of data collection (63\%), and with access to scientific information $(77 \%)$.

The result of the computerized analysis by NVivo 9.0 obtained 1696 Record Units (RUs), distributed into seven categories representing 100\% of the corpus analyzed. In this study, the number two category is broadened, comprising 277 RUs, distributed in 21 themes relating to $16.3 \%$ of the corpus, called "The hospital institution and its infrastructure: hub of vulnerability and empowerment in sociosymbolic constructs of nurses that care for patients with HIV/AIDS."

Although vulnerability is the object of study of this research, ways of coping with the state of vulnerability emerged in the discursive production of the nurses. These will be included as components of human empowerment. Because it has affective, attitudinal, symbolic, practical, cognitive and other dimensions, ${ }^{2}$ empowerment will be approached as an object of representation, which emerged in association with vulnerability. Considering the complexity of the results, their discussion will be carried out on two axes, the distinction of which is more didactic than real in the representational framework of the study participants.

\section{Axis 1 - The difficulties imposed by hospital} infrastructure on the practice of nursing care

In this axis, the precarious working conditions at the hospital are revealed by the subjects as a factor detrimental to the plenitude of their care practices. A negative attitude exists (unfavorable positioning) among the nurses interviewed about the scenario in which they work: [...] the infrastructure issues, which include furniture, the location, and that we often need support and don't get it! [...]. So we need continual maintenance of doors, fans, equipment, and this hasn't happened. We ask, but we aren't served to in a timely manner! And it generates anxiety, because we ask and don't get a response (e24).

It is noteworthy that the attitudinal dimension is central in the Social Representations Theory, and from its point of view, whether favorable or unfavorable, it is linked to the positioning of a group about an object of representation. ${ }^{10}$

In the psychosocial constructs of the nurses, their vulnerability is at least partly a product of the lack of an efficient ventilation system, in the absence of responses to requests for materials, the inadequacy of equipment, and objectified in the anguish generated by these factors. These expressions reflect the weakness perceived by the subjects of this study, who appear to have some degree of dissatisfaction and psychophysical wear, arising mainly from precarious work conditions with respect to human and material resources. These results are similar to those identified by another recently published study. ${ }^{4}$

The sharing of vulnerability, a concept explored in previous research, ${ }^{2}$ was found in the discursive process of the nurses, because in their representational content, some elements of everyday care simultaneously weaken them and patients physically or psychologically.

When we are going to puncture the patient, it is very embarrassing because the beds are very low [...]. It's uncomfortable for the professional and the patient (e3); We have horrible beds. If you raise the back, it doesn't go back down. We do not have adequate furniture. The least we can offer a person when he is sick is comfort. I think that if he requires more intensive care, we have an infusion pump. But nothing beyond that (e25).

In the above statement, this facet of social representations of vulnerability is suffering due to the suffering of another, in which the nurses, when perceiving the difficulties of providing care to patients due to the precarious resources and 
infrastructure of the hospital, feel distressed, uncomfortable, frustrated and embarrassed. Vulnerability, which makes sense in the embarrassment suffered, in this case threatens the subjects in their subjective and physical dimensions. ${ }^{14-15}$ The basic inputs for work are also pointed to by the nurses as lacking: [...] We don't use the goggles because they are not available (e14).

The lack of adequate equipment, particularly Personal Protective Equipment (PPE), weakens the professionals because it can increase their susceptibility to infection by certain pathogens. With regard to the use of PPE, the nursing staff may sometimes prioritize the care of another over themselves. ${ }^{7}$ Despite recognition of the situation, the negative attitude due to the lack of resources for work, verbalization of feelings of fear and insecurity, and the adoption of behaviors that reduce the risk of accidents, ${ }^{6}$ the study participants strive to justify the established situation: [...] now, this mask costs four dollars. My understanding is that this is why I only receive it once a month (e20); [...] I do not have a personal protective mask provided by the unit. Because we are from the outpatient unit. The risk is lower. And we care for AIDS, not tuberculosis (e27).

The lack of human resources in qualitative and quantitative aspects constitutes a factor that interferes in care, and gives the nurses a greater degree of vulnerability. ${ }^{2}$ The nurses recognize there is a lack of time for the work required, caused by the shortage of human resources: [...] It's the workload and insufficient number of professionals. And the nurses have a very large administrative overload (e10); [...] like it or not, the professionals get more tired and more stressed (e25).

The lack of a sufficient number of staff negatively affects the care provided by, and quality of professional life of the nurses. In this context, their vulnerability is reflected in the expressions of being "at the limit," "overwhelmed" and "stressed out." The study subjects point out that the lack of professionals presents an opportunity to overcome the deficit, which overwhelms them. This sense of being overwhelmed, an imagery dimension of the representation identified, has been noted by previous studies among nursing professionals, and is attributed to inadequate working conditions, long hours, low pay and ethical conflicts between nurses and their respective workplaces, among other institutional factors. ${ }^{8,16}$ Furthermore, the lack of vacancies available at other institutions to transfer patients who require more technologically- complex care appears as a barrier that is sometimes insurmountable for nurses, which comes from the disconnection between the policies advocated by the public health system and their day-to-day institutional implementation. It is very difficult to ask for a vacancy at the general hospital. So I get anxious because they do not want to take the patient. I want to take the patient onto my lap and carry her to the ICU [Intensive Care Unit]. So I get desperate! I see the patient dying (e21).

In general, nurses can face the death of patients with terminal illnesses as an inherent fact of human life, ${ }^{7}$ but when death is caused by dependency on another institution, department and/or professional, it appears to cause anguish, despair and other forms of psychological distress to the workers, ${ }^{4,7-8}$ who undertake efforts to provide technological resources to meet the needs of patients with AIDS.

The vulnerability expressed in the sense of technical unpreparedness and lack of initiatives for lifelong learning exhibits a cognitive dimension of the representation, and can be perceived in the following statements: I think it's important, in addition to specialization, to always take refresher courses. So I think that's what's missing in the hospital, an incentive for nurses to take courses (e5).

The sum of the factors that overwhelm the professional causes harm by generating a greater a degree of vulnerability to physical injuries and psychological damage, and by moving him/her to carry out their work in a mechanical manner, without being possible to develop skills, abilities and knowledge in performing his/her praxis. ${ }^{8}$

\section{Axis 2 - Empowerment in relationships between nurses and the hospital}

In opposition to the representational constructs related to vulnerability are those of empowerment, the conformation of which includes the hospital's positive characteristics, ranging from aspects of its infrastructure to the organization of nurses' work, which positively impact the care by nursing and promote wellness in the workplace, satisfaction with the care provided, and a greater sense of control over the care process. ${ }^{2}$

The presence of a positive attitude in the representation of empowerment can be perceived, given that the nurses position themselves favorably to hospital cleanliness. Cleanliness of the hospital environment appears to provide the nurses with a sense of well being, and contributes to its 
value among this professional group. Unlike other hospitals, here I don't smell blood, feces and urine. [...]. The cleaning here is very well done (e20).

This information is important in nursing, because concern with the influence of the environment on nursing care is based on a theoretical construct of great prominence in this profession, that being Florence Nightingale's environmental theory. ${ }^{17}$

In addition, there is a cognitive dimension to empowerment based on the perception of empowerment and autonomy in the everyday care experienced in the institution, which are linked to the sense of freedom and recognition. That is, the relationship between professional and environment of care, with regard to freedom of action, appears to be favorable, which causes the nurses to feel more capable, strengthened, resolute, autonomous and satisfied with their work, ${ }^{14,17-18}$ and therefore more empowered: [...] nurses have a lot of respect here in this hospital. We have considerable autonomy (e25).

This finding was reported in a previous study that examined the social representation of autonomy among nurses from the basic and hospital care network. ${ }^{18}$ The authors of this research, in addition to identifying the presence of elements such as "freedom," "knowledge" and "achievement," highlight the procedural nature of the autonomy of nursing in the psychosocial constructs of the nurses.

Teamwork was positively evaluated by the subjects, who are in favor of it. They affirm that they maintain positive relationships with other professionals, whether nurses or not. Real affection is perceived in the representations identified, and the nurses use the term "family" to describe the team with which they work. I like it here much more than my other jobs. I think, in terms of staff, it is very cool, it's more like a family. The staff respects us. The staff is unified. We are recognized. Both physicians as well as nursing assistants. There's no fighting to see who knows more. Quite on the contrary! (e1); [...] it is acceptable for the nurse to give an opinion about a patient. The physician listens, researches, will try to see. So I think it's a good interaction (e12).

The nurses also perceive themselves as collaborators in the provision of care by multidisciplinary teams. If there is any complication that exceeds their jurisdiction of operation, they feel they can turn to other professionals, in particular to the physicians, because, according to the study subjects, physicians have confidence in scientific knowledge and control of the situation by the nurse: [...] over time, we were able to gain respect for nursing. The nurses have respect [...]. If I have to take a patient now and insert a catheter, I'll insert it. Because I know what I'm doing. I know it was necessary. And tomorrow, I will communicate to the physician: 'doctor, I inserted the catheter based on this, this and this.' And he will understand. [...] people respect. They know that the nursing staff takes a lot of care. And we are there twenty-four hours a day. So, if it was done, it was because it was necessary. And the patients also respect this (e25).

The subjects attribute their role on the health care team to the existence of multidisciplinary work, by perceiving themselves as the link between its members, important sources of information and, above all, by staying beside the patient with HIV/AIDS 24 hours a day. Feeling safe means to feel respected and valued before the team, which is consistent with the notion of empowerment used in this research. Professional recognition has been identified as a factor that contributes to the worker's health, whether demonstrated by words, gestures, gifts or looks. ${ }^{7}$ For this reason, recognition is an important aspect for the formation of a greater level of empowerment perceived.

As part of the representation of empowerment, autonomy and professional recognition have characteristics that are worth highlighting. In this discursive formation of the study subjects, autonomy is the result of an arduous process of gaining respect from the other members of the healthcare team. Professional recognition was expressed as understanding and acceptance by other professionals of the decisions made by nurses. This form of empowerment is constituted in a space ceded by the other, from the intimate relationships that they maintain. In other words, if the autonomy of nurses is objectified in a selfaffirming positioning in the search for respect, professional recognition is anchored in the strong affection present in interpersonal relationships between nurses and other professionals.

The team acts to warn about the seropositive status of the patient, even though adherence to standard precautions does not require this explicitly: [...] depending on who goes to give the puncture, a signal is always given to the other: 'the patient is HIV positive. Be careful!' (e26).

This practical dimension of the representation of empowerment seems to stem from the fear 
of the unknown proportioned by social memories constructed in the beginning of the epidemic. ${ }^{1}$ The threat of risk perceived by some members of the nursing staff seems to provoke the use of cautionary measures not only for him/herself, but for the whole group, in an effort to protect the other. By generating a certain degree of complicity among some members of the nursing team, coexistence becomes a solid basis for the sharing of personal and professional problems, as well as protection of each other against some of the dayto-day problems. ${ }^{7}$

Mutual zeal and overcoming suffering on the team were shown to be actions that generate motivation, despite the weight of the workload and density of the everyday touched by the disease, fragility and death: It [work with HIV/ AIDS] ends up generating a very heavy emotional load, because I deal with the issue of death every day. Because there is always someone who is very ill or dying. And at this moment, despite that sector being heavy, the team rose to the situation [...] (e16).

It is perceived that among other forms of support, psychological comfort is one way of coping with the emotional charge generated by the environment of working with HIV/AIDS. This finding is different from that identified by another study, ${ }^{8}$ in which subjects used detachment and denial of feelings, when there is a lack of motivation and work overload. Another emerging aspect to the representations developed by the nurses are adaptations and improvisations in the face of absence of some materials needed for care: [...] because sometimes you can't help all of the patients. So I always try to help the serious cases (e5); [...] I won't have cotton, but I'll have gauze. I won't have alcohol, but I'll have other things to be able to do that cleaning (e17).

In the universe of practices present in the representational set, there is a clear attempt by the nurses to adapt to the shortage of human resources and materials for performing procedures. The practical dimension of the representation of empowerment, based on improvisation, in this sense, appears as a plausible strategy to circumvent possible harm to the care identified by the subjects of this study. In this way, nurses can perceive in the interim between the criteria recommended by science and/or standards established by the hospital, and concrete action of care. ${ }^{7}$ This is a space in which the professional lacks subjectivity to find ways of performing care in the best way possible.

\section{DISCUSSION}

Social representations are rooted in the concepts developed by human groups, as products of continuous interactions and the worldviews of its members. At the same time, it allows for understanding of the behavior of populations in their complexity, by providing access to affective, symbolic, and attitudinal dimensions, among others. ${ }^{9-11}$ It is therefore postulated that the nurses interviewed for this study verbalize their psychosocial constructions embedded in the work environment in which they operate, since their speech, behavior and social practices in the face of situations of vulnerability and empowerment are supports for transmitting social representations in the hospital institution. . $^{2,1}$

It confirms that the subjects are immersed in a system of humanistic, selfless and altruistic values, which is in accordance with the code of conduct advocated in the profession of nursing. ${ }^{17-19}$ Nevertheless, despite the nurse being key to the achievement of the institutional mission of the hospital, this immersion puts on their shoulders an ethical commitment to patient recovery and excellence of care provided, the possibility of which tends to be limited in the face of infrastructural, political and human and material resources limitations that are imposed on them. . $^{1820-21}$

The disorganization of work, ${ }^{14-15}$ the discouragement caused by its atmosphere, and tensions that arise within the HIV/ AIDS sector ${ }^{1-2,22}$ are characterized as some of the major sources of distress for nurses in the study. As an object of representation of nurses, vulnerability is marked by precarious service and unhealthy activity, which reinforce the presence of imminent risk and exposure in their symbolic constructions. ${ }^{22-24}$ The discourse of the subjects of this study highlights the circumscription of the dynamics maintained between vulnerability and empowerment. This dynamics of contradiction, already referred to as the vulnerability-empowerment dyad, ${ }^{2}$ is the movement of balance and counterbalance that competes to achieve the balance necessary for maintenance of harmony between the elements that weaken and strengthen human beings. ${ }^{25}$

At the psychosocial level, the constant imbalance between vulnerability and empowerment can impair the way of living of people for two distinct reasons. The first is linked to the permanence of the status of vulnerable, which, in the case of the nurses in this study, refers to being affected by the daily challenges they face 
with feelings of embarrassment, dissatisfaction, distress, frustration, insecurity, overload, stress and unpreparedness. By presenting themselves as participating elements of the representation of the state of vulnerable among nurses, these may discourage the exercise of the profession, which can only be avoided by redemption of the status of empowered, presented in the form of favorable interpersonal relationships with patients/staff, obtaining moral or operational support from other professionals, training services, the adoption of measures of self-protection, and the practice of adaptations and improvisations.
The second reason is that vulnerability feeds back into empowerment, because it contributes to the definition of the elements that constitute it. It is important to highlight that the elements participating in the psychosocial construction of empowerment have the functionality to compensate for the perceived vulnerability status. Nevertheless, at certain times in which context proves to be unfavorable to the nurses, the status of vulnerable overlaps that of empowered. This contradictory movement is characteristic of the dyad formed by vulnerability and empowerment, and mediated by the elaborated social representations (Figure1).

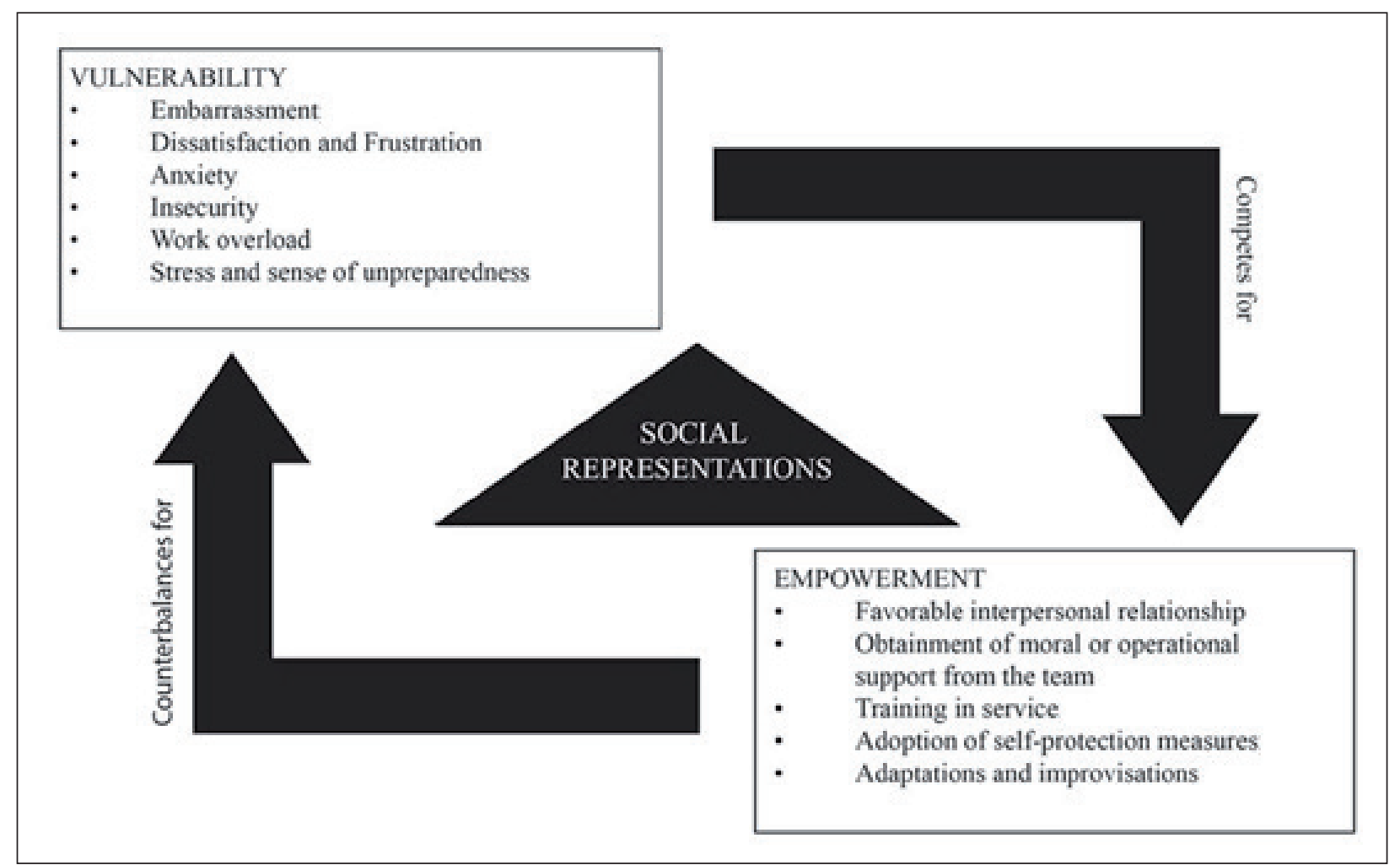

Figure 1 - Schematic illustration of the vulnerability-empowerment dyad in the context of the relationships between nurses and their work environment with seropositive patients. Rio de Janeiro-RJ

\section{CONCLUSION}

In conclusion, the results point to the resignification of contexts of vulnerability and empowerment, closely linked to the arrangements of the workplace in the context of HIV/AIDS. Thus, social representations act as mediators between a perceived status of greater weakness or strength, in movements of mutual contradiction.

The way vulnerability manifests itself in daily nursing care consists of a phenomenon of great importance to the science of nursing, taking into consideration the psychosocial understanding of the behaviors, values, attitudes, practices and images, which enunciate how nurses understand the concept and state of vulnerability day to day in the hospital, under the aegis of HIV/ AIDS.

The arrangements of the work environment of nurses comprise various forces that move in support of or against the fullness of care and the caregiver's health. Despite the efforts of nurses to succeed in the actions employed, numerous 
institutional, technological, political and social barriers pit one against the other, which weakens the professionals in their multiple dimensions.

Given the limited number of subjects included in this study, as well as its realization in a restricted location, further research is required, from other viewpoints and approaches, the expressions of vulnerability in relationships between nurses and working environment, inside and outside the context of communicable diseases. Nurses who perform their work activities in hospitals lack government and institutional policies directed towards their appreciation, recognition, encouragement, horizontal relationships, resolution of the problems they face and in-service training. These measures contributed to prevent illness as a result of the work process, and to promote a healthier work environment, in which the practices of nursing care and health may be full, resolute, effective and satisfactory for everyone involved.

\section{REFERENCES}

1. Gomes AMT. A vulnerabilidade como elemento organizador do cuidado de enfermagem no contexto do HIV/aids: conceitos, processos e representações sociais [tese]. Rio de Janeiro (RJ): Universidade do Estado do Rio de Janeiro. Faculdade de Enfermagem; 2011.

2. Santos ÉI. Vulnerabilidade de enfermeiros no cuidado a pacientes com HIV/aids: um estudo de representações sociais [dissertação]. Rio de Janeiro (RJ): Universidade do Estado do Rio de Janeiro. Faculdade de Enfermagem; 2012.

3. Barra DCC, Lanzoni GMM, Maliska ICA, Sebold LF, Schlindwein BH. Processo de viver humano e a enfermagem sob a perspectiva da vulnerabilidade. Acta Paul Enferm. 2010 Nov-Dez; 23(6):831-6.

4. Carter MA. Trust, power, and vulnerability: a discourse on helping in nursing. Nurs Clin North Am. 2009 Dez; 44(4):393-405.

5. Feito L. Vulnerabilidad. An Sist Sanit Navar. 2007 Set; 30(Supl3):7-22.

6. Sailer GC, Marziale MHP. Vivência dos trabalhadores de enfermagem frente ao uso dos antirretrovirais após exposição ocupacional a material biológico. Texto Contexto Enferm. 2007 Jan-Mar; 16(1):55-62.

7. Azambuja EP, Pires DEPP, Vaz MRC, Marziale MH. É possível produzir saúde no trabalho da enfermagem? Texto Contexto Enferm. 2010 OutDez; 19(4):658-66.

8. Meneghini F, Paz AA, Lautert L. Fatores ocupacionais associados aos componentes da Síndrome de Burnout em trabalhadores de enfermagem. Texto
Contexto Enferm. 2011 Abr-Jun; 20(2):225-33.

9. Moscovici S. A representação social da psicanálise. Rio de Janeiro (RJ): Zahar Editores; 1978.

10. Jodelet D. Folie et représesentations sociales. Paris (FR): PUF; 1989.

11. Sá CP. A construção do objeto de pesquisa em representações sociais. Rio de Janeiro (RJ): EdUERJ; 1998.

12. Bardin L. Análise de conteúdo. Lisboa (PT): Edições 70; 2006.

13. Oliveira DC. Análise de conteúdo temáticocategorial: uma proposta de sistematização. Rev Enferm UERJ. 2008 Out-Dez; 16(4):569-76.

14. Santos JM, Oliveira EB, Moreira AC. Estresse, fator de risco para a saúde do enfermeiro em centro terapia intensiva. Rev Enferm UERJ. 2006 Out-Dez; 14(4):580-5.

15. Souza NVDO, Lisboa MTL. Os múltiplos e contraditórios sentidos do trabalho para as enfermeiras: repercussões da organização e do processo laboral. Ciênc Cuid Saúde. 2006 Set-Dez; 5(3):326-34.

16. Gaudine A, Thorne L. Nurses' ethical conflict with hospitals: a longitudinal study of outcomes. Nurs Ethics. 2012 Nov; 19(6):727-37.

17. Nightingale F. Notas sobre enfermagem: o que é e o que não é. São Paulo (SP): Cortez; 1989.

18. Gomes AMT, Oliveira DC. Estudo da estrutura da representação social da autonomia profissional em enfermagem. Rev Esc Enferm USP. 2005 Jun; 39(2):145-53.

19. Thorup CB, Rundqvist E, Roberts C, Delmar C. Care as a matter of courage: vulnerability, suffering and ethical formation in nursing care. Scand J Caring Sci. 2012 Set; 26(3):427-35.

20. Olinski SR, Lacerda MR. Cuidando do cuidador no ambiente de trabalho: uma proposta de ação. Rev Bras Enferm. 2006 Jan-Fev; 59(1):100-4.

21. Gomes AMT, Oliveira DC, Santos ÉI, Santo CCE, Valois BRG, Pontes APM. As facetas do convívio com o HIV: formas de relações sociais e representações sociais da aids para pessoas soropositivas hospitalizadas. Esc Anna Nery. 2012 Mar; 16(1):111-20.

22. Guido LA, Linch GFC, Pitthan LO, Umann J. Estresse, coping e estado de saúde entre enfermeiros hospitalares. Rev Esc Enferm USP. 2011 Dez; 45(6):1434-9.

23. Santos ÉI, Gomes AMT, Oliveira DC, Santo CCE. Between suffering and pleasure: vulnerability to nurses in their interpersonal relationships with HIV / AIDS patients. Rev enferm UERJ. 2013 Jan;21(1):9-15.

24. Chen W, Han M. Knowledge, attitudes, perceived vulnerability of Chinese nurses and their preferences 
for caring for HIV-positive individuals: a crosssectional survey. J Clin Nurs. 2010 Nov; 19(21-22): 3227-34.
25. Sellman D. Towards an understanding of nursing as a response to human vulnerability. Nurs Philos. 2005 Jan; 6(1):2-10.

Universidade Federal Fluminense, Departamento de Enfermagem 